\title{
COMPARISONS OF SECULAR AND SEASONAL VARIATIONS IN THE INCIDENCE OF ANENCEPHALUS IN BELFAST AND FOUR SCOTTISH CITIES, 1956-66
}

\author{
J. H. ELWOOD and G. MacKENZIE \\ Department of Social and Preventive Medicine, The Queen's University, Belfast
}

EPIDEMIOLOGICAL investigations in the United Kingdom have shown that the secular and seasonal variations in the incidence of anencephalus in Belfast (Elwood, 1970) resemble those in Scotland (Record, 1961; Leck and Record, 1966). In both areas a small but definite increase in frequency and a significant excess of anencephalic births in winter compared with summer have occurred in recent years, this secular trend differing from the decline reported in Birmingham, England, by Leck (1966). Outside the United Kingdom a marked decline in incidence has been observed in New York State (Gittelsohn and Milham, 1962) and in Boston (Naggan, 1969), the latter city also exhibiting an excess of anencephalic births in summer. Owing to the large geographical area of Scotland we have compared the secular trends and variations by season in Belfast with those in four major Scottish cities, namely Aberdeen, Dundee, Edinburgh, and Glasgow, observed over the period 1956-66. In addition, we examined, using multivariate analysis, the associations between the monthly number of anencephalic births and certain meteorological components of season based on data from Belfast, Glasgow, and Edinburgh. Because no convincing explanation has yet been offered for the apparent significant seasonal variation in the monthly incidence of anencephalic births, we tested the hypothesis that the monthly number of cases was independent of air temperature, rainfall, and sunshine occurring at certain times during the gestational period of these pregnancies. The specific hypothesis and analytical methods adopted are detailed later.

\section{MATERIAL}

The Belfast data were from records of the municipal health department and a research register relating to all live births and stillbirths of 28 or more weeks of gestation delivered to city residents which has been maintained by the University Departments of Social and Preventive Medicine and
Medical Statistics since 1957 (Stevenson and Warnock, 1959). Further details are available in the first report on anencephalus in Belfast (Elwood, 1970). The hitherto unpublished Scottish data were provided by the Registrar General for Scotland, based on all registered anencephalic stillbirths (I.C.D. Y 38.0) and infant deaths (I.C.D. 750) delivered to women resident in the four selected cities. The diagnosis anencephalus (W.H.O., 1957) includes this malformation alone or in combination with one or more additional abnormalities.

The meteorological data were from the monthly weather reports of the Meteorological Office, Air Ministry, London. As we wished to consider as near as possible the exact levels of air temperature and amounts of rainfall and sunshine experienced by all the mothers, some of whom had anencephalic offspring, in these cities we based the four components of season on recordings made at the following meteorological stations: for Belfast (lat. $54^{\circ} 40^{\prime} \mathrm{N}$, long. $05^{\circ} 58^{\prime} \mathrm{W}$ ), Aldergrove, Co. Antrim (lat. $54^{\circ} 39^{\prime} \mathrm{N}$, long. $06^{\circ} 13^{\prime} \mathrm{W}$ ); for Glasgow (lat. $55^{\circ} 50^{\prime} \mathrm{N}$, long. $04^{\circ} 20^{\prime} \mathrm{W}$ ), Springburn Park, Lanarkshire (lat. $55^{\circ} 53^{\prime} \mathrm{N}$, long. $04^{\circ} 14^{\prime} \mathrm{W}$ ); and for Edinburgh (lat. $55^{\circ} 58^{\prime} \mathrm{N}$, long. $03^{\circ} 10^{\prime} \mathrm{W}$ ), Royal Botanic Gardens, Midlothian (lat. $55^{\circ} 58^{\prime} \mathrm{N}$, long. $03^{\circ} 12^{\prime} \mathrm{W}$ ). These readings are judged accurate (Meteorological Office, 1969) and all the stations are situated adjacent to the urban communities studied.

\section{MeTHODS}

In order to investigate whether the monthly numbers of anencephalic births were influenced by climatic factors, season was arbitrarily separated into four components corresponding to observations made in each month of the period 1955-66 as follows: the daily maximum air temperature $\left({ }^{\circ} \mathrm{C}\right)$ recorded during the month irrespective of the day on which it occurred $\left(x_{1}\right)$; similarly, the daily minimum air temperature $\left({ }^{\circ} \mathrm{C}\right)$ recorded on one day during the month $\left(\mathrm{x}_{2}\right)$; thirdly, the total amount of rainfall in millimetres $\left(x_{3}\right)$; and, fourthly, the 
average daily number of hours of sunshine $\left(x_{4}\right)$. The number of anencephalics born in each month of the 11 years 1956-66 was then related to these four components of season prevailing in each of the preceding nine months corresponding to the gestational periods of these abnormal pregnancies (Meteorological Office, 1955-66).

Changes in climate may be associated with abnormally high or low prevalence rates for certain diseases, e.g., low air temperature and respiratory infections, rickets and the absence of sunlight. Furthermore, it has been shown tnat extremes of climate usually cause most effect because the human body is able to maintain homeostasis until certain physiological and biochemical thresholds are reached. The position regarding anencephalus differs slightly owing to the defect probably being initiated during the first gestational month although it is not apparent until several months later. We therefore decided to investigate whether extremes of air temperature and the amounts of rainfall and sunshine experienced by three samples of expectant mothers were associated with a significantly high or low monthly number of anencephalics at subsequent delivery. The known interrelationships between the four selected climatic factors necessitated the use of a technique capable of separating out their individual effects; hence a multivariate model seemed appropriate. The null hypothesis that the number of anencephalic births in a month was independent of the four meteorological indices observed in that same month or in any of the preceding eight months was tested for the cities of Belfast, Edinburgh, and Glasgow. The statistical model used to describe the data postulated that the relationship between the monthly number of anencephalic births (y) and the four components of season is of the form-

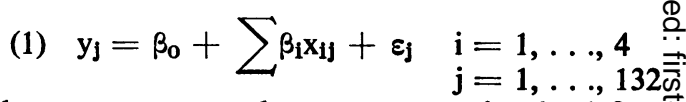
where $x_{1}, x_{2}, x_{3}$, and $x_{4}$ are as previously definet Using (1) the transformed values of the month numbers of anencephalics were regressed on the fot meteorological indices recorded in the first gest tional month. Eight further analyses were carrieg out in which the values of the dependent variable were identical with those of the first analysis but the values of $x_{1}, \ldots, x_{4}$ differed according to the gestational month in which they were recordes. Thus the first analysis employed the values off $\mathrm{x}_{1}, \ldots, \mathrm{x}_{4}$ observed in the month which preceded $y_{f}$ by eight months, the second analysis the values of $\mathrm{x}_{1}, \ldots, \mathrm{x}_{4}$ which preceded $\mathrm{y}_{\mathrm{j}}$ by seven month: etc., until the ninth analysis used values of $\mathrm{x}_{1}, \ldots, \mathrm{x}_{4}$ observed in the same month as the anencephalics were born. This procedure was carried out separately for Belfast, Edinburgh, andh Glasgow. A square root transformation of the dependent variable was used as it was found th the frequency distribution of anencephalic births per month was Poisson in type.

\section{RESULTS}

The present data (Table I) show that the incidence of anencephalus in $1956-66$ was $4 \cdot 1,3 \cdot 3,3 \cdot 2,2 \cdot 8$ and 1.8 per 1,000 total births in Belfast, Dundeg Glasgow, Edinburgh, and Aberdeen respectively The estimate for Dundee is identical with that made by Walker and Smith (1961) for this city observed over the period 1950-59, and the low rate in Aber

TABLE I

NUMBERS OF TOTAL BIRTHS, STILLBIRTHS AND INFANT DEATHS ATTRIBUTED TO ANENCEPHALUS, AND INCIDENCE PER 1,000 TOTAL (LIVE AND STILL) BIRTHS IN BELFAST AND FOUR SCOTTISH CITIES, 1956-66

\begin{tabular}{|c|c|c|c|c|c|c|c|c|c|c|c|}
\hline \multirow{2}{*}{$\begin{array}{c}\text { Year } \\
\text { of } \\
\text { Birth }\end{array}$} & \multicolumn{2}{|c|}{ Belfast } & \multicolumn{2}{|c|}{ Glasgow } & \multicolumn{2}{|c|}{ Edinburgh } & \multicolumn{2}{|c|}{ Dundee } & \multicolumn{3}{|c|}{ Aberdeen } \\
\hline & $\begin{array}{l}\text { Total } \\
\text { Births }\end{array}$ & $\begin{array}{c}\overline{\text { Anencephalics }} \\
\text { No. Rate }\end{array}$ & $\begin{array}{l}\text { Total } \\
\text { Births }\end{array}$ & $\begin{array}{c}\text { Anencephalics } \\
\text { No. Rate }\end{array}$ & $\begin{array}{l}\text { Total } \\
\text { Births }\end{array}$ & $\begin{array}{c}\text { Anencephalics } \\
\text { No. Rate }\end{array}$ & $\begin{array}{l}\text { Total } \\
\text { Births }\end{array}$ & $\begin{array}{l}\text { Anencephalics } \\
\text { No. Rate }\end{array}$ & $\begin{array}{l}\text { Total } \\
\text { Births }\end{array}$ & $\begin{array}{l}\text { Anenceph } \\
\text { No. }\end{array}$ & \\
\hline $\begin{array}{l}1956 \\
1957 \\
1958 \\
1959 \\
1960 \\
1961 \\
1962 \\
1963 \\
1964 \\
1965 \\
1966\end{array}$ & $\begin{array}{l}\mathbf{8 , 4 6 0} \\
\mathbf{8 , 5 1 9} \\
\mathbf{8 , 4 3 9} \\
\mathbf{8 , 4 2 4} \\
\mathbf{8 , 8 9 5} \\
\mathbf{8 , 9 9 3} \\
\mathbf{8 , 8 2 7} \\
\mathbf{8 , 9 5 3} \\
\mathbf{8 , 8 4 5} \\
\mathbf{8 , 4 8 8} \\
\mathbf{8 , 3 1 9}\end{array}$ & $\begin{array}{lll}27 & (3) & 3 \cdot 2 \\
39 & (6) & 4 \cdot 6 \\
38 & (5) & 4 \cdot 5 \\
30 & (5) & 3 \cdot 6 \\
36 & (7) & 4 \cdot 0 \\
47 & (9) & 5 \cdot 2 \\
38 & (11) & 4 \cdot 3 \\
29 & (8) & 3 \cdot 2 \\
40 & (6) & 4 \cdot 5 \\
34 & (2) & 4 \cdot 0 \\
33 & (9) & 4 \cdot 0\end{array}$ & $\begin{array}{l}22,461 \\
23,015 \\
23,356 \\
23,211 \\
23,665 \\
23,388 \\
24,028 \\
23,110 \\
22,852 \\
21,277 \\
20,163\end{array}$ & $\begin{array}{lll}63 & (6) & 2 \cdot 8 \\
79 & (12) & 3 \cdot 4 \\
75 & (7) & 3 \cdot 2 \\
73 & (6) & 3 \cdot 1 \\
78 & (9) & 3 \cdot 3 \\
92 & (14) & 3 \cdot 9 \\
70 & (10) & 2 \cdot 9 \\
85 & (10) & 3 \cdot 7 \\
57 & (4) & 2 \cdot 5 \\
74 & (3) & 3 \cdot 5 \\
64 & (4) & 3 \cdot 2\end{array}$ & $\begin{array}{l}\mathbf{7 , 6 4 3} \\
\mathbf{8 , 0 0 7} \\
\mathbf{8 , 0 1 9} \\
\mathbf{8 , 3 1 1} \\
\mathbf{8 , 6 0 9} \\
\mathbf{8 , 5 3 2} \\
\mathbf{8 , 8 9 3} \\
\mathbf{8 , 6 6 0} \\
\mathbf{8 , 9 1 7} \\
\mathbf{8 , 4 9 2} \\
\mathbf{7 , 9 2 4}\end{array}$ & $\begin{array}{lll}30 & (1) & 3 \cdot 9 \\
20 & (1) & 2 \cdot 5 \\
24 & (1) & 3 \cdot 0 \\
27 & (-) & 3 \cdot 3 \\
37 & (1) & 4 \cdot 3 \\
25 & (1) & 2.9 \\
19 & (-) & 2 \cdot 1 \\
21 & (3) & 2.4 \\
24 & (2) & 2 \cdot 7 \\
11 & (2) & 1 \cdot 3 \\
22 & (2) & 2 \cdot 8\end{array}$ & $\begin{array}{l}3,510 \\
3,539 \\
3,651 \\
3,654 \\
3,812 \\
3,759 \\
3,815 \\
3,837 \\
3,877 \\
3,744 \\
3,375\end{array}$ & 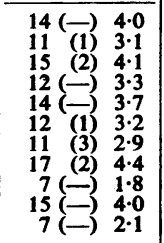 & $\begin{array}{l}3,342 \\
3,429 \\
3,295 \\
\mathbf{3}, 406 \\
\mathbf{3}, 349 \\
3,314 \\
\mathbf{3}, 303 \\
\mathbf{3}, 385 \\
\mathbf{3}, \mathbf{1 8 5} \\
\mathbf{3 , 2 6 6} \\
\mathbf{2 , 9 3 7}\end{array}$ & $\begin{array}{c}8(-) \\
5(-) \\
8(1) \\
8(-) \\
7(-) \\
11(-) \\
1(-) \\
4(-) \\
6(-) \\
2(-)\end{array}$ & $\begin{array}{l}2.5 \\
1.5 \\
2.50 \\
2.4 \\
2.100 \\
3.5 \\
0.80 \\
1.20 \\
1.05 \\
1.85 \\
0.0\end{array}$ \\
\hline$\overline{1956-66}$ & 95,162 & $391(71) 4 \cdot 1$ & 250,526 & $810(85) \quad 3 \cdot 2$ & 92,007 & 260 (14) $2 \cdot 8$ & 40,573 & 135 (9) $3 \cdot 3$ & 36,211 & 66 (1) & \\
\hline
\end{tabular}

-Figures in parentheses are numbers of anencephalic infant deaths and are included in the totals which they follow. 
deen was also found by Anderson, Baird, and Thomson (1958) in their study of 1950-55 data.

\section{Secular Variations}

Several studies of the Registrar General's statistics relating to all anencephalic stillbirths registered in Scotland since 1939 have found a small overall increase in incidence although with marked fluctuations from year to year (Edwards, 1958; Record, 1961). The rate in Scotland appears to have risen and fallen twice in the last 30 years, the first peak occuring in 1942-3 and the second in 1960-1 (Leck and Rogers, 1967). These are similar to the secular changes reported from Birmingham (MacMahon, Record, and McKeown, 1951; Leck, 1966). The present analysis based on a different time period and including live as well as stillborn anencephalics shows small overall decreases during 1956-66 in Aberdeen, Dundee, and Edinburgh and no measurable change in Glasgow (Table II). None of these secular trends is significant. Inspection of the secular variations (Fig. 1) suggests that trends in Belfast are most similar to those in Glasgow.

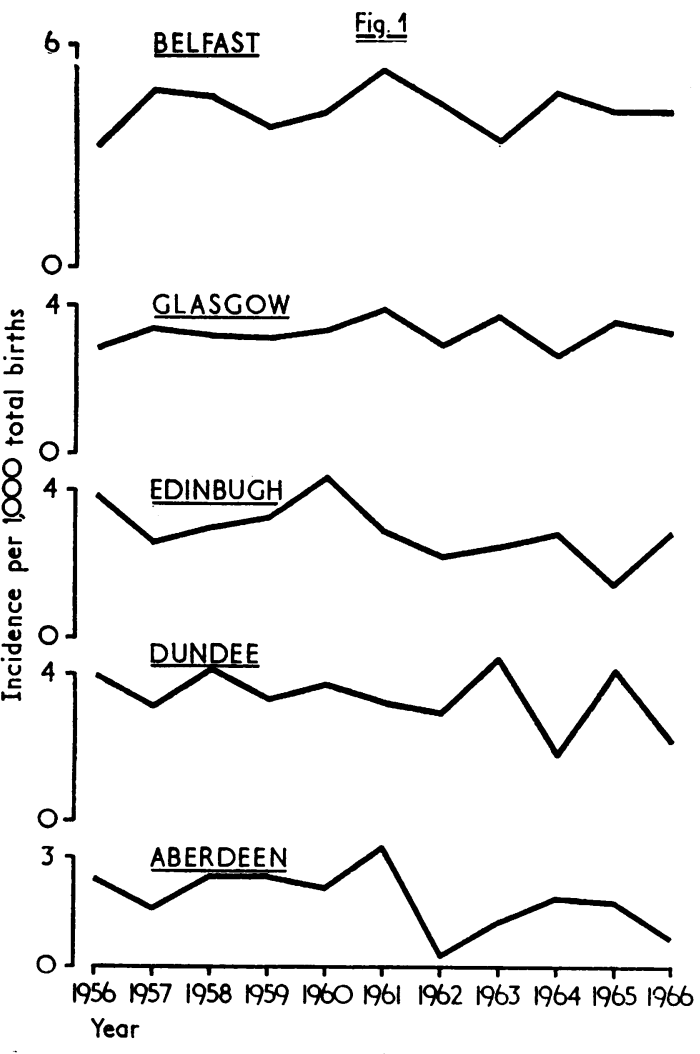

\section{SEasonal Variations}

Differences between the distributions of anencephalics by month of birth in the five cities are evident (Table III; Fig. 2). Because the proportions of anencephalics certified as live born and later registered as infant deaths are not the same, being $19.2 \%, 10.5 \%, 6.6 \%, 5.4 \%$, and $1.5 \%$ in Belfast, Glasgow, Dundee, Edinburgh, and Aberdeen respectively, the analysis of seasonal variations was based on affected stillbirths and infant deaths so that ascertainment was as complete as possible. The null hypothesis that there was no difference between the monthly observed number of anencephalic births and that expected assuming an equal proportion of the total occurring in each month was tested, and significant $(\mathrm{P}=0.05)$ seasonal trends were found in Belfast, Glasgow, and Edinburgh. Tests of the numbers observed in winter and summer, defined as first plus last and second plus third quarters of the same year respectively, compared with an expectation of equal proportions show a significant summer excess in Aberdeen $\left(\chi^{2}=3.88\right.$; D.F. $=1$; $0.05>P>0.02)$ and a winter excess in Glasgow

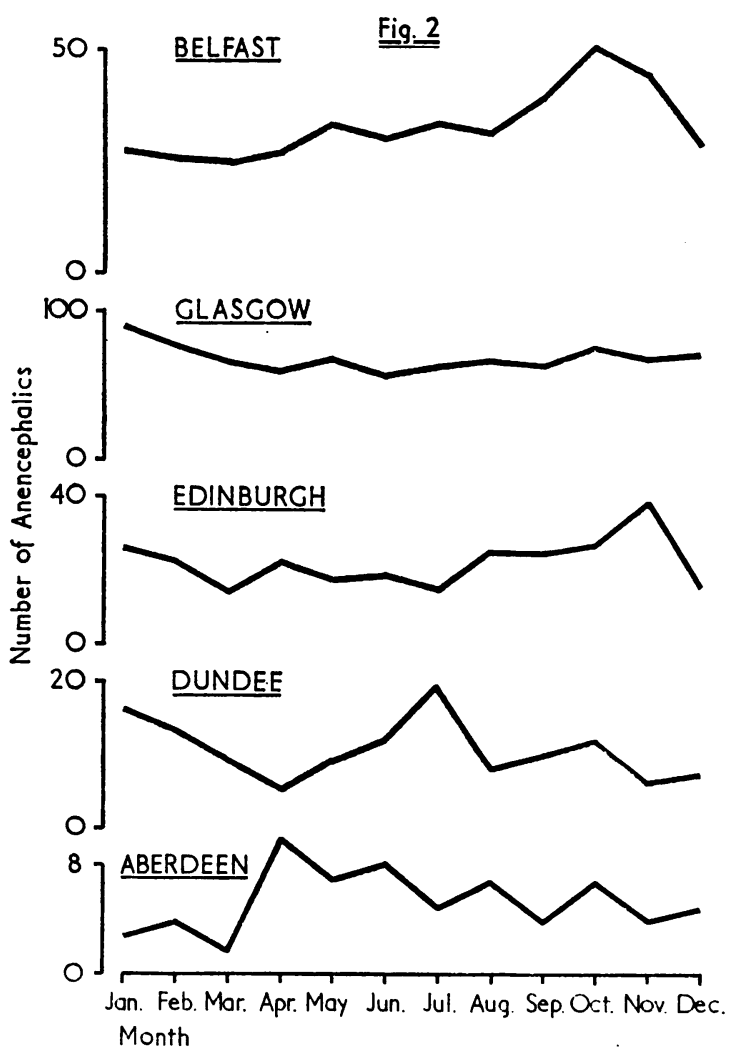


TABLE II TESTS OF LINEARITY BASED ON REGRESSING THE TRANSFORMED PROPORTION* $\left(\sin ^{-1} \sqrt{ }\right.$ p) OF
ANENCEPHALICS OCCURRING ANNUALLY OVER THE PERIOD $1956-66$ IN EACH CITY

\begin{tabular}{|c|c|c|c|c|c|}
\hline City & Mean & $\begin{array}{l}\text { Constant and } \\
\text { Standard Error }\end{array}$ & Probability & $\begin{array}{c}\text { Regression } \\
\text { Coefficient } \\
\text { and } \\
\text { Standard Error }\end{array}$ & Probability \\
\hline $\begin{array}{l}\text { Belfast } \\
\text { Glasgow } \\
\text { Edinburgh } \\
\text { Dundee } \\
\text { Aberdeen }\end{array}$ & $\begin{array}{l}3 \cdot 66 \\
3 \cdot 26 \\
3 \cdot 01 \\
3 \cdot 29 \\
2 \cdot 36\end{array}$ & $\begin{array}{l}3.63 \pm \mathbf{0 . 0 2} \\
3.24 \pm \mathbf{0 . 1 3} \\
3.49 \pm 0.23 \\
3.65 \pm \mathbf{0 . 2 4} \\
\mathbf{2 . 9 0} \mathbf{0} .36\end{array}$ & $\begin{array}{l}0 \cdot 001 \\
0 \cdot 001 \\
0 \cdot 001 \\
0 \cdot 001 \\
0.001\end{array}$ & $\begin{array}{r}+0.01 \pm 0.03 \\
0.00 \pm 0.02 \\
-0.08 \pm 0.04 \\
-0.06 \pm 0.04 \\
-0.09 \pm 0.06\end{array}$ & $\begin{array}{l}0.90>P>0.80 \\
0.90>P>0.80 \\
0.10>P>0.05 \\
0.20>P>0.10 \\
0.20>P>0.10\end{array}$ \\
\hline
\end{tabular}

*Proportion, $\mathrm{p}=\frac{\text { number of anencephalic (stillbirths and infant deaths) }}{\text { number of births (live and still) }}$ per annum.

$\left(\chi^{2}=6.76\right.$; D.F. $\left.=1 ; 0.01>\mathrm{P}>0.001\right)$, the Belfast and Edinburgh trends not being significant.

\section{Influence of Climatic Factors}

Statistically the occurrence of an anencephalic is a relatively rare event occurring in about 1 in 500 pregnancies to women resident in the British Isles. It was therefore thought likely that the frequency distribution of cases per month might be Poissonian; such was found to be the case in all five cities (Table IV). However, owing to the relatively smaller numbers of anencephalics in Aberdeen and Dundee during 1956-66 and the absence of any apparent significant seasonal variation (Table III) these two cities were omitted from the multivariate analysis now described. In the remaining three cities the meteorological data relating to the first gestational month are similar, with the exception of monthly total rainfall, Glasgow having the highest and Edinburgh the lowest (Table V). Also it is noted that there is not only a high positive correlation between $x_{1}$ and $x_{2}$, as might be expected, but also between each of these temperature factors and the sunshines index $x_{4}(T a b l e ~ V I)$. The necessary criteria for validu application of simple least squares analysis were examined as appropriate, particularly in relation to $\dot{\vec{v}}$ the presence of serial correlation which is known too occur in time series data. None was found significantly to affect any of the present results (Durbint and Watson, 1951).

The zero order (Table VII) and the partiae correlation coefficients (Table VIII) are of simila magnitude although some differ in direction, hences indicating a degree of confounding between the independent variables. Interpretation of the assockis: tions between the dependent variable and each 9 the four independent variables after eliminating the confounding effects of the other three in turn (Tableo VIII) may be interpreted as follows. Consider theo Belfast analysis relating to gestational month $1 \stackrel{\circ}{\circ}$ when a number of fetuses $(\mathrm{y})$, ascertained retrospec- $\overrightarrow{\vec{O}}$ tively to be anencephalics, were aged 4 weeks or less. 3 The monthly number of anencephalics is significantly? negatively correlated with the maximal air tempera-

TABLE III

DISTRIBUTIONS OF ANENCEPHALICS (STILLBIRTHS AND INFANT DEATHS) BY MONTH OF BIRTH AND CITY, 1956-66

\begin{tabular}{|c|c|c|c|c|c|}
\hline Month of Birth & Belfast & Glasgow & Edinburgh & Dundee & Aberdeen \\
\hline $\begin{array}{l}\text { January } \\
\text { February } \\
\text { March } \\
\text { April } \\
\text { May } \\
\text { June } \\
\text { July } \\
\text { August } \\
\text { September } \\
\text { October } \\
\text { November } \\
\text { December }\end{array}$ & $\begin{array}{l}27 \\
25 \\
25 \\
27 \\
33 \\
29 \\
33 \\
31 \\
39 \\
50 \\
44 \\
28\end{array}$ & $\begin{array}{l}90 \\
77 \\
66 \\
59 \\
66 \\
55 \\
61 \\
65 \\
62 \\
74 \\
66 \\
69\end{array}$ & $\begin{array}{l}25 \\
22 \\
14 \\
21 \\
17 \\
18 \\
15 \\
25 \\
24 \\
26 \\
38 \\
15\end{array}$ & $\begin{array}{r}17 \\
14 \\
10 \\
6 \\
10 \\
12 \\
20 \\
9 \\
10 \\
12 \\
7 \\
8\end{array}$ & $\begin{array}{r}3 \\
4 \\
2 \\
10 \\
7 \\
8 \\
5 \\
7 \\
4 \\
7 \\
4 \\
5\end{array}$ \\
\hline Total & 391 & 810 & 260 & 135 & 66 \\
\hline Peak Month & October & January & November & July & April \\
\hline $\begin{array}{l}\chi^{2} \\
\text { D.F. } \\
\text { Probability }\end{array}$ & $\begin{array}{c}21 \cdot 1 \\
11 \\
0.05-0.01\end{array}$ & $\begin{array}{c}29 \cdot 6 \\
11 \\
0.01-0.001\end{array}$ & $\begin{array}{c}25 \cdot 0 \\
11 \\
0.01-0.001\end{array}$ & $\begin{array}{c}16 \cdot 4 \\
11 \\
0 \cdot 20-0 \cdot 10\end{array}$ & $\begin{array}{c}10 \cdot 7 \\
11 \\
0.50-0 \cdot 30\end{array}$ \\
\hline
\end{tabular}


TABLE IV

FREQUENCY DISTRIBUTIONS OF THE OBSERVED NUMBERS OF ANENCEPHALICS (STILLBIRTHS AND INFANT DEATHS) IN EACH MONTH COMPARED WITH EXPECTED NUMBERS BASED ON THE POISSON DISTRIBUTION, 1956-66

\begin{tabular}{|c|c|c|c|c|c|c|c|c|c|c|}
\hline \multirow{2}{*}{$\begin{array}{l}\text { No. of Cases } \\
\text { per Month } \\
x\end{array}$} & \multicolumn{2}{|c|}{ Belfast } & \multicolumn{2}{|c|}{ Glasgow } & \multicolumn{2}{|c|}{ Edinburgh } & \multicolumn{2}{|c|}{ Dundee } & \multicolumn{2}{|c|}{ Aberdeen } \\
\hline & Obs. & Exp. & Obs. & Exp. & Obs. & Exp. & Obs. & Exp. & Obs. & Exp. \\
\hline $\begin{array}{r}0 \\
1 \\
2 \\
3 \\
4 \\
5 \\
6 \\
7 \\
8 \\
9 \\
10 \\
11 \\
12 \\
13 \\
14 \\
15\end{array}$ & $\begin{array}{r}7 \\
18 \\
33 \\
32 \\
20 \\
11 \\
3 \\
6 \\
2\end{array}$ & $\begin{array}{r}6 \cdot 84 \\
20.25 \\
29.97 \\
29 \cdot 57 \\
21 \cdot 88 \\
12.95 \\
6 \cdot 39 \\
2.70 \\
1.45\end{array}$ & $\left.\begin{array}{r}1 \\
1 \\
8 \\
15 \\
16 \\
12 \\
25 \\
14 \\
15 \\
11 \\
7 \\
3 \\
2 \\
-2\end{array}\right\}$ & $\begin{array}{r}0.29 \\
1.75 \\
5.37 \\
10.98 \\
16.84 \\
20.67 \\
21.14 \\
18.53 \\
14.22 \\
9.69 \\
5.95 \\
\\
6.56\end{array}$ & $\left.\begin{array}{r}18 \\
42 \\
34 \\
18 \\
11 \\
6 \\
0 \\
2 \\
1\end{array}\right\}$ & $\begin{array}{r}18.41 \\
36.26 \\
35.72 \\
23.46 \\
11.55 \\
4.55 \\
2.05\end{array}$ & $\left.\begin{array}{l}48 \\
48 \\
24 \\
10 \\
1 \\
1\end{array}\right\}$ & $\begin{array}{r}47 \cdot 60 \\
48 \cdot 68 \\
24 \cdot 89 \\
8 \cdot 49 \\
2 \cdot 34\end{array}$ & $\left.\begin{array}{r}82 \\
38 \\
9 \\
2 \\
1\end{array}\right\}$ & $\begin{array}{l}80.06 \\
40.03 \\
10.01 \\
1.91\end{array}$ \\
\hline $\begin{array}{l}\text { Mean } \\
\text { Variance }\end{array}$ & & & & & & & & & & \\
\hline $\begin{array}{l}\chi^{2} \\
\text { D.F. } \\
\text { Probability }\end{array}$ & & & & & & & & & & \\
\hline
\end{tabular}

TABLE V

MEAN VALUES AND RANGE OF OBSERVATIONS OF THE FOUR INDEPENDENT VARIABLES ASSOCIATED WITH FIRST GESTATIONAL MONTH USED IN REGRESSION ANALYSES

\begin{tabular}{|c|c|c|c|c|}
\hline City & $\frac{\begin{array}{c}\text { Air Temperature } \\
\left(\max { }^{\circ} \mathbf{C}\right)\end{array}}{\left(\begin{array}{c}x_{1} \\
\text { (range) }\end{array}\right.}$ & $\frac{\begin{array}{c}\text { Air Temperature } \\
\left(\min ^{\circ} \mathbf{C}\right)\end{array}}{\begin{array}{c}x_{2} \\
\text { (range) }\end{array}}$ & 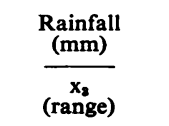 & 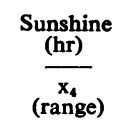 \\
\hline $\begin{array}{l}\text { Belfast } \\
\text { Glasgow } \\
\text { Edinburgh }\end{array}$ & $\begin{array}{c}17.0 \\
(5.0 \text { to } 27.8) \\
17.2 \\
(7.2 \text { to } 33.9) \\
17.6 \\
(6.1 \text { to } 28.3)\end{array}$ & $\begin{array}{l}-1 \cdot 2 \\
(-12 \cdot 8 \text { to }+6 \cdot 8) \\
(-11.7 \text { to }+8.9) \\
-(-11.8 \text { to }+8.9)\end{array}$ & $\begin{array}{c}68.2 \\
(9.0 \text { to } 161.0) \\
83.6 \\
(17.0 \text { to } 190.0) \\
53 \cdot 0 \\
(7.0 \text { to } 184.0)\end{array}$ & $\begin{array}{c}3.5 \\
(0.7 \text { to } 9.6) \\
(0.2 \text { to } 9.4) \\
3.7 \\
(0.8 \text { to } 9.0)\end{array}$ \\
\hline
\end{tabular}

TABLE VI

CORRELATION COEFFICIENTS BETWEEN FOUR CLIMATIC FACTORS OCCURRING DURING FIRST GESTATIONAL MONTH

\begin{tabular}{|c|c|c|c|c|c|c|c|c|c|}
\hline \multirow{2}{*}{ Factor } & \multicolumn{3}{|c|}{ Belfast } & \multicolumn{3}{|c|}{ Edinburgh } & \multicolumn{3}{|c|}{ Glasgow } \\
\hline & $x_{2}$ & $x_{3}$ & $x_{6}$ & $x_{2}$ & $x_{3}$ & $x_{6}$ & $x_{2}$ & $x_{3}$ & $x_{4}$ \\
\hline 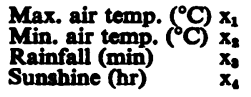 & 0.77 & $\begin{array}{l}0.07 \\
0.22\end{array}$ & $\begin{array}{r}0.72 \\
0.47 \\
-0.23\end{array}$ & 0.84 & $\begin{array}{l}0.18 \\
0.25\end{array}$ & $\begin{array}{r}0.77 \\
0.67 \\
-0.19\end{array}$ & 0.84 & $\begin{array}{l}0.03 \\
0.17\end{array}$ & $\begin{array}{r}0.79 \\
0.59 \\
-0.25\end{array}$ \\
\hline
\end{tabular}

TABLE VII

ZERO ORDER CORRELATION COEFFICIENTS ASSOCIATED WITH EACH MONTH OF GESTATION: DATA FOR BELFAST, EDINBURGH, AND GLASGOW, 1956-66

\begin{tabular}{|c|c|c|c|c|c|c|c|c|c|c|c|c|}
\hline \multirow{2}{*}{$\begin{array}{l}\text { Gestational Period } \\
\text { (months) }\end{array}$} & \multicolumn{4}{|c|}{ Belfast } & \multicolumn{4}{|c|}{ Edinburgh } & \multicolumn{4}{|c|}{ Glasgow } \\
\hline & \multicolumn{2}{|c|}{$\begin{array}{l}\text { Correlation } \\
\mathbf{x}_{\mathbf{1}} \quad \mathrm{x}_{\mathbf{2}} \\
\end{array}$} & \multicolumn{2}{|c|}{\begin{tabular}{rr}
\multicolumn{2}{l}{ Coefficients } \\
$\mathrm{x}_{\mathbf{3}}$ & $\mathrm{x}_{\mathbf{4}}$ \\
\end{tabular}} & \multicolumn{2}{|c|}{$\begin{array}{l}\text { Correlation } \\
\mathrm{x}_{\mathbf{1}} \quad \mathrm{x}_{\mathbf{2}} \\
\end{array}$} & \multicolumn{2}{|c|}{$\begin{array}{l}\text { Coefficients } \\
\mathrm{x}_{\mathbf{8}} \quad \mathrm{x}_{\mathbf{4}}\end{array}$} & \multicolumn{2}{|c|}{$\begin{array}{l}\text { Correlation } \\
\mathrm{x}_{1}\end{array}$} & \multicolumn{2}{|c|}{$\begin{array}{l}\text { Coefficients } \\
x_{3} \quad x_{4}\end{array}$} \\
\hline $\begin{array}{l}1 \\
2 \\
3 \\
4 \\
5 \\
6 \\
7 \\
8 \\
9\end{array}$ & $\begin{array}{l}-0.25 \\
-0.20 \\
-0.09 \\
+0.04 \\
+0.14 \\
+0.25 \\
+0.23 \\
+0.18 \\
+0.08\end{array}$ & $\begin{array}{l}-0.17 \\
-0.21 \\
-0.16 \\
-0.05 \\
+0.15 \\
+0.21 \\
+0.25 \\
+0.24 \\
+0.06\end{array}$ & $\begin{array}{r}-0.16 \\
-0.15 \\
-0.14 \\
-0.05 \\
-0.16 \\
+0.08 \\
+0.11 \\
+0.15 \\
+0.01\end{array}$ & $\begin{array}{r}-0.14 \\
-0.12 \\
+0.09 \\
+0.18 \\
+0.17 \\
+0.16 \\
+0.12 \\
+0.06 \\
+0.01\end{array}$ & $\begin{array}{r}-0.07 \\
0.00 \\
+0.14 \\
+0.19 \\
+0.25 \\
+0.24 \\
+0.15 \\
+0.05 \\
-0.11\end{array}$ & $\begin{array}{r}-0.13 \\
-0.02 \\
+0.06 \\
+0.16 \\
+0.18 \\
+0.21 \\
+0.17 \\
+0.04 \\
-0.02\end{array}$ & $\begin{array}{r}-0.17 \\
-0.13 \\
-0.06 \\
-0.05 \\
+0.09 \\
+0.01 \\
+0.13 \\
+0.01 \\
+0.01\end{array}$ & $\begin{array}{c}+0.01 \\
-0.01 \\
+0.18 \\
+0.21 \\
+0.19 \\
+0.17 \\
+0.01 \\
+0.04 \\
-0.19\end{array}$ & $\begin{array}{l}+0.03 \\
+0.17 \\
+0.15 \\
+0.18 \\
+0.10 \\
+0.03 \\
-0.08 \\
-0.14 \\
-0.16\end{array}$ & $\begin{array}{r}+0.11 \\
+0.11 \\
+0.14 \\
+0.13 \\
+0.16 \\
+0.02 \\
0.00 \\
-0.08 \\
-0.15\end{array}$ & $\begin{array}{r}+0.03 \\
0.00 \\
+0.03 \\
+0.10 \\
+0.03 \\
0.00 \\
+0.11 \\
-0.02 \\
+0.08\end{array}$ & $\begin{array}{l}+0.15 \\
+0.15 \\
+0.15 \\
+0.15 \\
-0.04 \\
-0.03 \\
-0.13 \\
-0.12 \\
-0.25\end{array}$ \\
\hline
\end{tabular}

Significant at $5 \%$ level, 


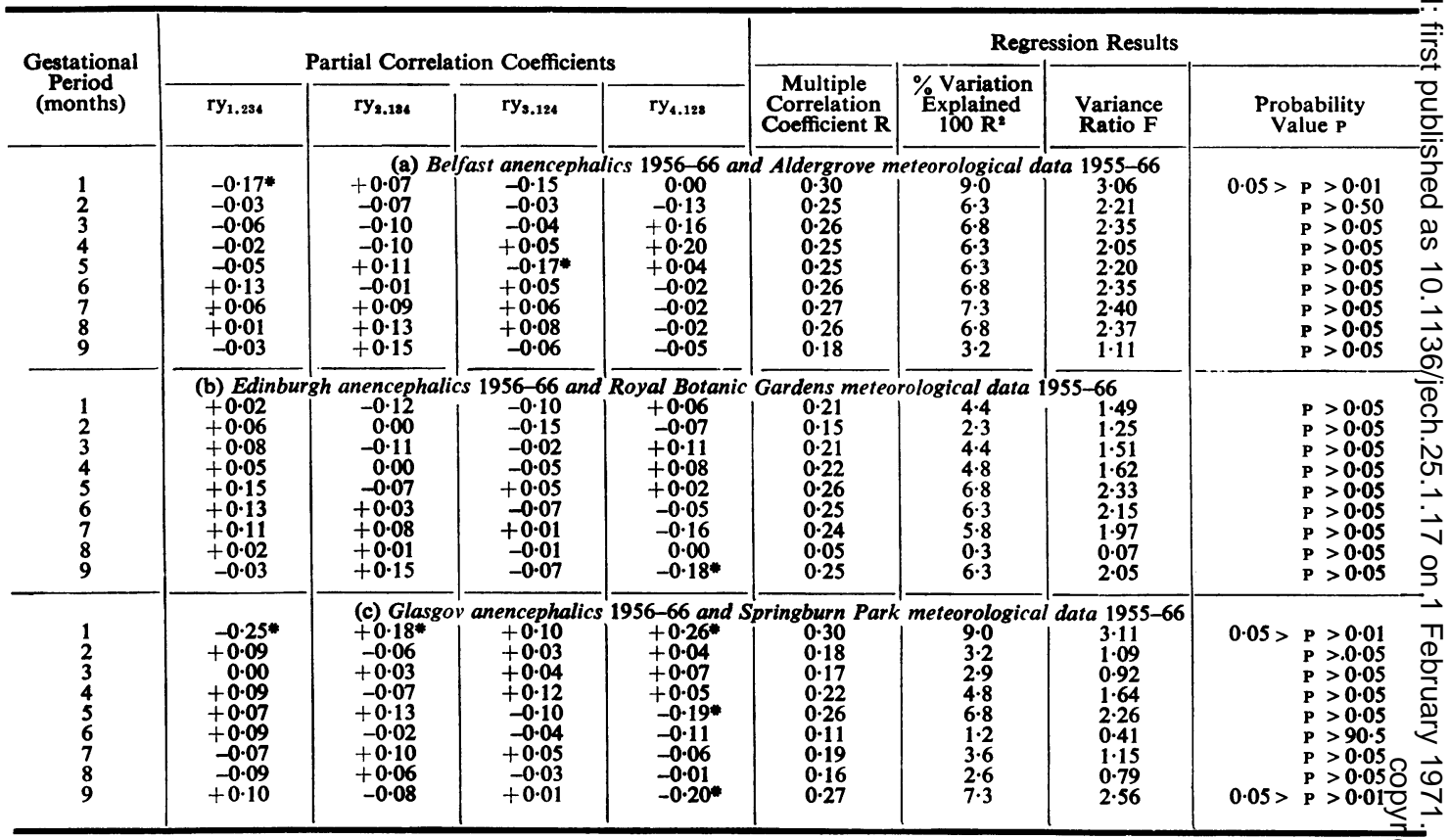

- Significant at $5 \%$ level with 127 degrees of freedom.

ture but is not significantly associated with the other three independent variables. For gestational month 2 corresponding to a fetal age of between 5 and 8 weeks none of the associations is significant. The remaining partial correlation coefficients are interpreted in similar fashion. Inspection of the results shows that the associations found between the monthly number of anencephalic births and the four independent variables are not consistent from city to city. Partial correlation coefficients reach significance at the first and fifth gestational months in Belfast, at the first, fifth, and ninth months in Glasgow, and at the ninth month in Edinburgh. Of the 108 coefficients available for testing, only $8(7 \%)$ are formally significant. The selected regression model explains a significant amount of the total variation in the monthly number of anencephalic births in $3(11 \%)$ out of the 27 sets of data examined and there is agreement between Belfast and Glasgow regarding the effect of maximal air temperature $\left(x_{1}\right)$ during the first gestational month, a probable time of initiation of this malformation.

\section{Discussion}

The geographical variation in incidence within Scotland has been noted previously (Edwards, 1958;
Anderson et al., 1958) but the fact that the nationat secular trend of an increase in frequency in recend years is not present in all of the four largest cities i. this country is a new finding. Similarly, the differ ences in the seasonal variations are of interest an $\bar{P}$ in particular the summer excess of anencephalic births in Aberdeen. Unfortunately, the number of cases studied is small but if this trend were confirmed: in a larger series, then Aberdeen together with Sout Wales (Laurence, Carter, and David, 1968) would be the only United Kingdom areas in which this phenomenon has been observed to date, all other British surveys having reported an excess of anence? phalic births in winter. It would appear that both the secular and seasonal variations in Belfast most closely resemble those in Glasgow and least resemble those in Aberdeen, with the Dundee and Edinburg trends being intermediate between these two conf trasting patterns. This could be explained by either genetic or environmental differences between the populations.

The hypothesis that season might influence conception rates (Mills and Senior, 1930; Macfate lane and Spalding, 1960) was investigated in relatio to parents of anencephalics in Birmingham by Leck and Record (1966) who found that these mothers 
did not have any unusual seasonal pattern of reproduction. These authors also considered evidence explaining seasonal variation by differential loss of conceptions in early pregnancy but thought that this hypothesis was unconvincing. It seems that the seasonal variation in the incidence of anencephalus associated with a relatively small geographical area, e.g., a city, differs between communities but that within a community the trend slowly changes over a period of years, as has been observed in Belfast (Elwood, 1970), Birmingham and Scotland (Leck and Record, 1966). These events, especially when observed in virtually the same gene pool, are very difficult to explain in genetic terms and are more likely to be environmental in origin. Before considering possible mechanisms by which seasonal factors might induce an anencephalic outcome of pregnancy it seemed to us that it should first be established whether in fact any association between these events exists and, if so, is this relationship real or spurious?

Climatic changes recognized by the four seasons of the year have affected man since earliest times and their effects on health were studied by Hippocrates (Kelly, 1938). Medical aspects have been comprehensively reviewed by Tromp (1963). Teratological experiments in animals (Giroud, 1960) and examination of human embryos (Streeter, 1948; Millen, 1963) have established that anencephalus is determined before the end of the fourth week after fertilization; hence our finding of a significant association between the monthly number of anencephalics and the maximal air temperature operating at this time in Belfast and Glasgow is of relevance. The qualitative analysis by Record (1961) suggesting that in Scotland the fetus is most vulnerable to anencephalus on the days when the mean number of hours of sunshine is highest was not clearly borne out by our quantitative study although the significant partial correlation coefficient $(r=+0.26)$ between the monthly number of anencephalics and the sunshine index $\left(x_{4}\right)$ in Glasgow is evidence of a weak association. The low order of all the correlation coefficients and the lack of repeatability of the findings in three independent sets of data suggest that climatic factors, as measured by the present method, appear not to be major although they may be minor determinants of the seasonal variation in anencephalus. The coefficients calculated are much lower than, for instance, those found when environmental temperature is correlated with the seasonal mortality from ischaemic heart disease $(r=-0.97$; Dunnigan, Harland, and Fyfe, 1970) or bronchitis and pneumonia ( $r=-0.90$; Hill, 1966). The significant relationships between the monthly number of anencephalic births and the four climatic indices operating in the second and third trimesters, when it is known that teratogenic agents are ineffective with regard to the production of this defect, suggest that these associations may be spurious. However, to some extent these correlations are affected by those anencephalics having gestation times of less than $\mathbf{4 0}$ weeks which comprise a substantial proportion of the total number of cases in each of the three samples investigated. The present study considered data on a monthly basis and thus, if the embryo were at risk for only a short period of a few days or less, then our findings of low associations might be expected. The problem of detecting such a shortacting phenomenon using epidemiological methods even if daily data were available, is considerable. Our results, therefore, do not by themselves exclude the existence of climatic effects but suggest rather that their mode of action must be other than that formulated by the current hypothesis.

le Vann (1963) in Alberta, using qualitative data, suggested that rainfall and congenital anomalies might be associated owing to the former being a carrier of radioactive dust, but further studies by Segall, MacMahon, and Hannigan (1964) were unable to show any definite link between current levels of background radiation and congenital malformations. Fedrick (1970) has recently reported highly significant correlations $(r=-0.80)$ between the incidence of anencephalus and various water factors in 10 areas of the United Kingdom. Soft acid waters may therefore act as a carrier or solvent of some as yet unidentified teratogen or alternatively they may be deficient in some substance essential for the normal development of fetuses conceived by a small group of 'at risk' women. However, Howe (1970), in a study of mortality from arteriosclerotic heart disease (I.C.D. No. 420) and other fatal conditions in Glasgow, has pointed out that although there is a high inverse correlation with the hardness of the water supply between cities, the within city variation is not so associated as all Glasgow receives the same soft water from Loch Katrine. Some wards in this city have standardized mortality ratios well below or well above $( \pm 30 \%)$ the national average for the United Kingdom with respect to I.C.D. No. 420 and this probably is true for anencephalus as well.

Our study would not appear to substantiate a major direct deleterious influence of climatic factors on the central nervous system of the 1-month-old fetus. Any effect, which seems to be weak, is more likely indirect and could possibly be mediated via an alteration in maternal metabolism, chemical constituents of diet or possibly replication of patho- 
logical organisms. The absence of any biologically plausible mechanism responsible for anencephalus makes investigations along these lines difficult although thermo-dependent and photosensitive effects often have a chemical or enzyme basis. A derangement of folic acid metabolism is a possible final common pathway as this fits with the observation of greatest susceptibility of fetuses conceived in the first quarter of the year, a time when the daily diet is likely to be relatively deficient in this essential substance. Preliminary evidence for (Hibbard, 1964; Hibbard and Smithells, 1965) and against (Emery, Timson, and Watson-Williams, 1969) this hypothesis is available and therefore further investigations of folic acid and other dietary constituents seem indicated.

\section{SUMMARY}

The secular and seasonal variations in the incidence of anencephalus occurring in all live births and still births of 28 or more weeks of gestation in Belfast, Aberdeen, Dundee, Edinburgh, and Glasgow were examined over the period 1956-66. The incidence showed a small overall increase in Belfast, no change in Glasgow, and a decrease in Aberdeen, Dundee, and Edinburgh. A winter excess of anencephalic births occurred in all cities except Aberdeen where there was an excess in summer.

Using multivariate techniques the associations between the monthly number of anencephalic births and four monthly indices of season based on observations of maximal and minimal air temperature, number of hours of sunshine, and total rainfall were measured using data for Belfast, Edinburgh, and Glasgow. Low but significant negative correlations with maximal air temperature occurring during the first month of gestation were found in Belfast and Glasgow but not in Edinburgh. It was concluded that variations in climate were associated with only a small proportion of the seasonal variations in the incidence of anencephalus.

We wish to thank the Registrar General for Scotland for generously providing the Aberdeen, Dundee, Edinburgh, and Glasgow data.

\section{REFERENCES}

ANDERson, W. J. R., BAIRD, D., and Thomson, A. M. (1958). Epidemiology of stillbirths and infant deaths due to congenital malformation. Lancet, 1, 1304.

Dunnigan, M. G., Harland, W. A., and FyFe, T. (1970). Seasonal incidence and mortality of ischaemic heart-disease. Lancet, 2, 793.

DURBIN, J., and WATSON, G. S. (1951). Testing for serial correlation in least squares regression. II. Biometrika, 38, 159.
EDWARDS, J. H. (1958). Congenital malformations of the $C$ central nervous system in Scotland. Brit. J. prev. soc. Med., 12, 115.

Elwood, J. H. (1970). Anencephalus in Belfast. Incidencee and secular and seasonal variations, 1950-66. Brit. J. prev. soc. Med., 24, 78.

Emery, A. E. H., Timson, J., and Watson-Williams, E. J. (1969). Pathogenesis of spina bifida. Lancet, 2,음 909.

FEDRICK, J. (1970). Anencephalus and the local water $\widehat{D}$ supply. Nature (Lond.), $227,176$.

GIROUD, A. (1960). Causes and morphogenesis of anencephaly. In Ciba Foundation Symposium on Con- $\overrightarrow{0}$ genital Malformations, ed. Wolstenholme, G. E. W., and O'Connor, C. M., p. 199. Churchill, London.

Girtelsohn, A. M., and MilhaM, S. (1962). Declining incidence of central nervous system anomalies in New York State. Brit. J. prev. soc. Med., 16, 153.

HibBaRD, E. D. (1964). The FIGLU excretion test andî defective folic-acid metabolism in pregnancy. Lancet, -$2,1146$.

$\longrightarrow$, and SMithells, R. W. (1965). Folic acid meta-o bolism and human embryopathy. Lancet, 1, 1254.

HILL, A. B. (1966). Principles of Medical Statistics, $\overrightarrow{-}$ 8th ed., p. 257. Lancet, London.

HowE, G. M. (1970). Some aspects of social malaise in Scotland. Hlth Bull. (Edinb.), 28, No. 1, p. 14.

KelLY, E. C. (1938). Translation of Hippocrates; 'OnK airs, waters and places'. In Medical Classics, Vol. $8, \overrightarrow{0}$ p. 19. Williams and Wilkins, Baltimore.

LaUREnCE, K. M., CarTer, C. O., and David, P. (1968). Major central nervous system malformations in South Wales. I. Incidence, local variations and geographical factors. Brit. J. prev. soc. Med., $22,146$.

LECK, I. (1966). Changes in the incidence of neural-tube defects. Lancet, 2, 791.

- , and RECORD, R. G. (1966). Seasonal incidence of $\frac{}{\Rightarrow}$ anencephalus. Brit. J. prev. soc. Med., $20,67$.

, and RoGERs, S. C. (1967). Changes in the incidence of anencephalus. Brit. J. prev. soc. Med., 21, 177.

LE VANN, L. J. (1963). Congenital abnormalities in? children born in Alberta during 1961: a survey and a hypothesis. Canad. med. Ass. J., 89, 120.

MaCfarlane, W. V., and Spalding, D. (1960). Seasonalo conception rates in Australia. Med. J. Aust., 1, 121.

MACMAHON, B., RECORD, R. G., and McKeOWN, T. (1951). Secular changes in the incidence of malformations of the central nervous system. Brit. J. soc. Med., 5, 254.

Metrorological OfFice (1969). Personal communica-D tion.

Air Ministry, London.

MILLEN, J. W. (1963). Timing of human congenitalN malformations, with a time-table of human develop-N ment. Develop. Med. Child Neurol., 5, 343.

Mills, C. A., and Senior, F. A. (1930). Does climate affect the human conception rate? Arch. intern. Med.,

46, 921 .
NAGGAN, L. (1969). The recent decline in prevalence of ? anencephaly and spina bifida. Amer.J. Epidem., 89, 154. 7 
RECORD, R. G. (1961). Anencephalus in Scotland. Brit. J. prev. soc. Med., 15, 93.

Segall, A., MacMahon, B., and Hannigan, M. (1964). Congenital malformations and background radiation in northern New England. J. chron. Dis., 17, 915.

Stevenson, A. C., and WARNOCK, H. A. (1959). Observations on the results of pregnancies in women resident in Belfast. I. Data relating to all pregnancies ending in 1957. Ann. hum. Genet., 23, 382.

STREETER, G. L. (1948). Developmental horizons in human embryos. Contr. Embryol. Carneg. Instn., 32, 133 [No. 211].
Tromp, S. W. (1963). Medical Biometeorology, Weather, Climate and the Living Organism. Elsevier, Amsterdam.

WALKER, J., and SMrTH, A. (1961). Anencephaly in Dundee, 1950-59. In First International Conference on Congenital Malformations, London, 1960, p. 257. Lippincott, Philadelphia.

World Health Organization (1957). Congenital malformations. In Manual of the International Statistical Classification of Diseases, Injuries, and Causes of Death, Seventh Revision (1955), Vol. 1, p. 219, Geneva. 